\title{
The Effect of Hypnotherapy using Induction Hanung Technique on the Level of Cigarette Dependence and Carbon Monoxide in Exhaled Breath among Active Smokers
}

\author{
Margiyati $^{1}$, Meidiana Dwidiyanti², Diyan Yuli Wijayanti ${ }^{3}$ \\ ${ }^{1}$ Student of Master Program in Nursing, Diponegoro University, Indonesia \\ ${ }^{2}$ Department of Nursing,Diponegoro University, Indonesia \\ ${ }^{3}$ Department of Nursing, Diponegoro University, Indonesia \\ Corresponding author: Meidiana Dwidiyanti (meidiana@fk.undip.ac.id)
}

\begin{abstract}
Background: Smoking is a habit that causes many health problems. Nicotine substances in cigarettes cause addiction and carbon monoxide inhaled is poisonous. Hypnotherapy using induction hanung technique is an alternative which can be used to change someone's smoking behaviors. This therapy is performed by giving hypnotic suggestions combined with a massage at acupuncture points of neguan, yintang, and taiyang.
\end{abstract}

Purpose:This study aimed to analyze the effects of hypnotherapy using induction hanung technique on the level of cigarette dependence and carbon monoxide in exhaled breath among active smokers in Kesdam IV/ Diponegoro College of Nursing, Semarang.

Methods: The present study employed a true-experimental pretest-posttest control group design. A total of 40 students were recruited as samples and randomly assigned to the intervention group $(n=20)$ and control group $(n=20)$. The intervention in the form of hypnotherapy using induction hanung technique was given for six times in two weeks. The instruments used were Fagerstorm Test for Cigarette Dependence (FTCD) and smokerlyzer. Data were analyzed with the Mann-Whitney test and independent t-test.

Results: The results showed a decrease in the score of cigarette dependence level in the intervention group by 1.25 after the intervention was given with pretest mean value of 1.45 ( $\mathrm{SD}=1.132)$. The result of Mann-Whitney test showed a significant difference in the cigarette dependence score between the intervention and control groups with a pvalue of 0.028 . The level of carbon monoxide in the exhaled breath also decreased by $8.80 \mathrm{ppm}$ after the intervention from the pretest mean values of 12.55 ( $\mathrm{SD}=6.669)$. The independent sample t-test result also showed a significant difference in the carbon monoxide level between the two groups with a p-value of 0.000 .

Conclusion: The present findings showed that hypnotherapy using induction hanung technique affected the level of cigarette dependence and carbon monoxide in exhaled breath among the active smokers. Based on the findings, this therapy is recommended as an alternative to nursing intervention for the smoking cessation programs.

Keywords: hypnotherapy, cigarette dependence; carbon monoxide

\section{Introduction}

Indonesia ranks first in the world as the country with the highest prevalence of smokers for male population aged over 15 years of $67.4 \% .{ }^{1}$ The high number of smokers have 
become a major threat to the health development since it increases the incidence of noncommunicable diseases such as coronary heart, stroke, cancer, chronic obstructive pulmonary and causes premature death with the loss of an average of eight years of productive life. ${ }^{2,3,4}$

It is proven that cigarette contains 4000 chemical substances that are detrimental to health. ${ }^{2,5}$ Cigarette smoke contains Carbon Monoxide (CO) with a concentration of more than 20,000 ppm and it is toxic. ${ }^{6}$ Cigarette also contains nicotine that cause dependence effect. ${ }^{7}$ Smokers who are trying to quit smoking will experience difficulties due to nicotine withdrawal symptoms such as anxiety, difficulty in concentrating, insomnia, and depression. ${ }^{8}$ Smokers with mild dependence eventually become severe and even find difficulty in the smoke-free area such as health care or education environment. ${ }^{7,9}$

Nurses are the most potential health workers who can play a role in cigarette control programs because nurses are the largest constituents of health personnel in quantity. ${ }^{10}$ Nurses most likely encounter many smokers in the realm of the community through a variety of preventive actions such as the counseling on dangers of smoking for vulnerable and at risk groups, carry out screening on smoking behavior and provide smoking cessation services equipped with therapy to prevent relapsed. ${ }^{11,12}$ This role is, however, ultimately contradictory when some nurses are identified to smoke cigarettes. ${ }^{13}$

Smoking habit in nurses is closely related to smoking in nursing education institutions because this behavior started at a young age before they get into professional world. ${ }^{13}$ Data showed that $50 \%$ of students have attended cigarette control training and also attended the subject of the dangers of smoking. However, there is no decrease in the number of smokers among nursing students. ${ }^{14}$ This phenomenon is also found in Kesdam IV/ Diponegoro College of Nursing with the preliminary study in December 2016 showed that $47 \%$ of male students are active smokers who know the dangers of smoking and the regulation of KTR in the campus but they find it difficult to quit smoking.

Hypnotherapy is a complementary therapy by using the art of communication to implant suggestions for a person to stop smoking. ${ }^{15}$ Hypnotherapy using induction Hanung technique is a hypnotic therapy conducted by modifying the induction phases with gentle messages at acupuncture points, namely: neguan, yintang, and taiyang. ${ }^{16}$ This technique is considered effective in guiding clients towards trance condition so that the suggestions to quit smoking easily implanted. The success of stopping the cigarette dependence during the treatment period will lower CO, discharge nicotine from the body and resolve nicotine withdrawal symptoms within 2 weeks. ${ }^{17}$

\section{Objectives}

The main objective of this study is to analyze the effect of hypnotherapy using induction Hanung technique on the level of cigarette dependence and carbon monoxide in exhaled 
HOLISTIK NURSING AND HEALTH SIENCE 1, (1), 2018 12-23

breath among active smokers in Kesdam IV/ Diponegoro College of Nursing, Semarang.

\section{Methodology}

The research design used was a true experimental pretest-posttest control group design. The study was conducted on May $8^{\text {th }}$ to May $26^{\text {th }}, 2017$ at stop smoking clinic Kesdam IV/ Diponegoro College of Nursing, Semarang. The population of this study were 44 active smokers in Kesdam IV/ Diponegoro College of Nursing Semarang in May 2017. Random allocation technique was employed to divide subjects randomly into intervention or control group. Samples taken must meet the inclusion criteria, such as: registered as students of Kesdam IV/ Diponegoro College of Nursing, active smokers with the level of carbon monoxide in exhaled breath of $\geq 7 \mathrm{ppm}$, not changing the smoking habit abruptly within the last 1 month, have a desire to stop smoking, aged 20 to 40 years old, male students, and live in the surrounding of Kesdam IV/Diponegoro College of Nursing Semarang. Meanwhile, the exclusion criteria determined were under going other therapy to quit smoking and dropping out for not being able to follow therapy on an agreed schedule. The samples were 40 respondents divided into intervention and control groups with 20 respondents for each.

Data were collected after obtaining the permission from Health Research Committee of Medical Faculty of Diponegoro University. The implementation of the research began with the counseling to quit smoking in the first day for all respondents. The next stage was filling characteristics of respondents instrument, self efficacy measurements using Visual Analog Scale (VAS) Stop Smoking instrument, cigarette dependence level measurements using Fagestrom Test for Cigarette Dependence (FTCD) instrument, and the carbon monoxide level measurement using smokerlyzer. Data collection and treatment were conducted by the researcher and 2 enumerators who have been certified as hypnotherapist by IBH and received training material of induction hanung technique. The treatment of hypnotherapy using induction hanung technique was conducted for 60 minutes per session for 6 times on the $2^{\text {nd }}, 4^{\text {th }}, 6^{\text {th }}, 9^{\text {th }}, 11^{\text {th }}, 13^{\text {th }}$ days, while post-test was conducted on the $14^{\text {th }}$ day. The collected data were analyzed using the Mann-Whitney test and independent t-test.

\section{Results}

\section{Characteristics of Respondents}

Table 1.Characteristics of Respondents in Intervention and Control Groups $(n=40)$

\begin{tabular}{ccc}
\hline \multirow{2}{*}{ Variable } & \multicolumn{2}{c}{ Group } \\
\cline { 2 - 3 } & Intervention $(\mathrm{n}=20)$ & Controls $(\mathrm{n}=20)$ \\
\hline
\end{tabular}




\begin{tabular}{lcccc}
\hline & $\mathrm{f}$ & $\%$ & $\mathrm{f}$ & $\%$ \\
\hline First Time Smoking at Age & & & & \\
$<15$ years & 8 & 40 & 4 & 20 \\
$\geq 15$ years & 12 & 60 & 16 & 80 \\
\hline Time of Smoking & 7 & 35 & 5 & 25 \\
$<5$ years & 8 & 40 & 11 & 55 \\
5-9 years & 4 & 20 & 2 & 10 \\
10-14 years & 1 & 5 & 2 & 10 \\
$>15$ years & & & & \\
Smoking Family & 10 & 50 & 9 & 45 \\
Yes & 10 & 50 & 11 & 55 \\
No & & & & \\
Smoking Friends & 20 & 100 & 19 & 95 \\
Yes & 0 & 0 & 1 & 5 \\
No & & & & \\
\hline Type of Cigarettes & 15 & 75 & 18 & 90 \\
Mild & 2 & 10 & 1 & 5 \\
Clove & 3 & 15 & 1 & 5 \\
Mixed & & & & \\
\hline Pattern of Smoking & 5 & 25 & 8 & 40 \\
Shallow & 15 & 75 & 12 & 60 \\
Deep & & & & \\
\hline
\end{tabular}

Table 1 shows that most respondents in both groups had the characteristics of first time smoking at age $\geq 15$ years, time of smoking is between 5-9 years, their family members do not smoke, hanging out with smoking friends, smoking mild cigarettes, and deep pattern of smoking.

\section{Level of Cigarette Dependence Before and After Treatment}

Table 2. Decrease in the Level of Cigarette Dependence Before and After Treatment in Intervention and Control Groups $(\mathrm{n}=40)$

\begin{tabular}{|c|c|c|c|c|c|c|}
\hline \multirow[t]{2}{*}{ Variable } & \multicolumn{2}{|c|}{$\begin{array}{l}\text { Intervention Group } \\
(\text { Mean } \pm \text { SD) }\end{array}$} & & \multicolumn{2}{|c|}{$\begin{array}{c}\text { Control Group } \\
\text { Mean } \pm \text { SD }\end{array}$} & \multirow[t]{2}{*}{$\mathrm{p}$} \\
\hline & Pre & Post & & Pre & Post & \\
\hline $\begin{array}{l}\text { Level of Cigarette } \\
\text { Dependence }\end{array}$ & $\begin{array}{l}(1.45 \pm \\
1.1317)\end{array}$ & $\begin{array}{l}(0.20 \pm \\
0.410)\end{array}$ & $0.001 *$ & $\begin{array}{l}(2,30 \pm \\
1.867)\end{array}$ & $\begin{array}{l}(1.90 \pm \\
1.683)\end{array}$ & 0.202 \\
\hline
\end{tabular}

Table 2 shows the mean in the level of cigarette dependence.There is significant decrease in the intervention group between pre and post where the value of $p=0.001$ ( $p$ $<\alpha, \alpha=0.05$ ), where as the control group did not experience significant decrease where the value of $p=0.202(p>\alpha, \alpha=0.05)$.

\section{Level of Carbon Monoxide in Exhaled Breath Before and After Treatment}


Table 3. Decrease in the level of CO in Exhaled Breath Before and After Treatment in intervention and control groups $(n=40)$

\begin{tabular}{|c|c|c|c|c|c|c|}
\hline \multirow[t]{2}{*}{ Variable } & \multicolumn{2}{|c|}{$\begin{array}{c}\text { Intervention Group } \\
(\text { Mean } \pm \text { SD) }\end{array}$} & \multirow[t]{2}{*}{$\mathrm{P}$} & \multicolumn{2}{|c|}{$\begin{array}{l}\text { Control Group } \\
\text { Mean } \pm \text { SD }\end{array}$} & \multirow[t]{2}{*}{$\mathrm{P}$} \\
\hline & Pre & Post & & Pre & Post & \\
\hline $\begin{array}{l}\text { Level of CO in } \\
\text { Exhaled Breath }\end{array}$ & $\begin{array}{l}(12.55 \pm \\
6.669)\end{array}$ & $\begin{array}{l}(3.75 \pm \\
4.552)\end{array}$ & $0,000 *$ & $\begin{array}{l}(12,45 \pm \\
6,932)\end{array}$ & $\begin{array}{l}(13.25 \pm \\
6.866)\end{array}$ & 0.474 \\
\hline
\end{tabular}

Table 3. shows the mean of level of $\mathrm{CO}$ in exhaled breath. There is significant decrease in the intervention group between pre and post where the value of $p=0.000(p<\alpha$, $\alpha=0.05)$, where as there is no significant decrease in control group where the value of $\mathrm{p}=0.474(\mathrm{p}>\alpha, \alpha=0.05)$.

\section{Level of Cigarette Dependence between Intervention and Control Group}

Table 4. Decrease in the Level of Cigarette Dependence between Intervention and Control Group after Treatment $(n=40)$

\begin{tabular}{cccc}
\hline \multirow{2}{*}{ Variable } & \multicolumn{2}{c}{ Mean \pm SD } & \multirow{2}{*}{$\mathrm{P}$} \\
\cline { 2 - 3 } & Intervention group & Control group & \\
\hline $\begin{array}{l}\text { Average Difference of } \\
\text { Cigarette Dependence }\end{array}$ & $(1.25 \pm 1.209)$ & $(0.40 \pm 1.353)$ & $\begin{array}{c}0.028 \\
*\end{array}$ \\
\hline
\end{tabular}

Table 4. shows the results of the analysis of the mean difference in pre and post on the level of cigarette dependence between intervention and control groups. There is a significant decrease in the value of $p=0,028(p<\alpha, \alpha=0,05)$.

\section{Level of Carbon Monoxide between Intervention and Control Group}

Table 5. Decrease in the Level of CO in Expired Breath between Intervention and Control Group After Treatment $(n=40)$

\begin{tabular}{lccc}
\hline \multirow{2}{*}{ Variable } & \multicolumn{2}{c}{ Mean \pm SD } & P \\
\cline { 2 - 3 } & Intervention Group & Control Group & \\
\hline $\begin{array}{l}\text { Average Difference in the Level } \\
\text { of CO in Exhaled Breath }\end{array}$ & $(8.80 \pm 5.425)$ & $(0.80 \pm 4.895)$ & $\begin{array}{c}0,000 \\
*\end{array}$ \\
\hline
\end{tabular}

Table 5 shows the result of analysis when mean difference between pre and post in the level of $\mathrm{CO}$ in exhaled breath. There is significant difference in the intervention and control group where the value of $p=0,000(p<\alpha, \alpha=0,05)$.

Relationship Between Self Efficacy with Level of Cigarette Dependence and Carbon Monoxide in Exhaled Breath 
HOLISTIK NURSING AND HEALTH SIENCE 1, (1), 2018 12-23

Table 6. Relationship between Self-Efficacy with Level of Cigarette Dependence and $\mathrm{CO}$ in Exhaled Breath among Active Smokers $(\mathrm{n}=40)$

\begin{tabular}{lcc}
\hline Relationship Variable & Correlation $\left(\mathrm{r}_{\mathrm{s}}\right)$ & $\mathrm{P}$ \\
\hline Self efficacy with level of cigarette dependence & $-0,647 * *$ & 0,000 \\
\hline Self efficacy with level of CO in exhaled breath & $-0,617 * *$ & 0,000 \\
\hline
\end{tabular}

Table 6. shows the results of post-intervention in the variable of self efficacy with the level of cigarette dependence which has negative correlation where $r_{s=} 0.647$. It means that the higher the score of self efficacy the lower the levels of cigarette dependence. Similar results were also obtained in the variable of self efficacy and the level of exhaled breath where $r_{s}=-0.617$, which means the higher the score of the self efficacy the lower the level of $\mathrm{CO}$ in exhaled breath among active smokers. The result of analysis on the relationship shows that $\mathrm{p}$ value $=0.000$ which means that there is significant relation between self efficacy, level of cigarette dependence, and level of CO in exhaled breath among active smokers.

\section{Discussion}

\section{Level of Cigarette Dependence Before and After Treatment}

The level of cigarette dependence in the intervention group decreased with a mean of pre $=1.45$ (SD 1.1317) and post $=0.20$ (SD 0.410). The result of paired sample $t-$ test shows the value of $p=0,001$ which means there is a significant difference before and after the hypnotherapy using induction hanung techniques. The findings of this study are consistent with the results of Noha and Seham's research showing that the hypnosis program gives a significant difference to smoking index score before and after therapy where the value of $\mathrm{p}=0.001$. $^{18}$

Hypnotherapy using induction hanung technique has systematic stages that influence person's smoking behavior. The treatment of hypnotherapy using induction hanung techniques through massage on the wrist, temples and forehead help the relaxation process and lead to shorter deepening phase and faster consciousness loss. This result is supported by Tiffany's research stating that massage at a certain point of the body can lower cortisol, increase serotonin and dopamine. ${ }^{19}$ This technique helps to condition the brain waves down from beta to alpha and teth, and put someone into a trance and the subconscious door open to communicate with. ${ }^{15,20}$ The subconscious is the center of habit, emotions, memory, and confidence in which hypnotherapists use this situation to implant suggestions such as strengthening the intention to quit smoking according to the date, reducing the number of cigarettes, doing self hypnosis, as well as do anchor when nicotine withdrawal symptoms appear. ${ }^{21}$

The mean level of cigarette dependence in the control group in pre-test was 2.30 $(\mathrm{SD}=1.867)$ and decreased in post-test into $1.90(\mathrm{SD}=1.683)$, with the Wilcoxon test results showed no significant difference since the value of $p=0.202$. These results prove that without the help of the method of quitting smoking, nicotine dependence becomes the main difficulty and tends to persist even if they have the desire to stop smoking. It is 
supported by the findings of Charlotte \& Mitchel stating that without the help, the success rate of stopping smoking was only 10\%. It is also supported by the LM3 (Institute for Coping with Smoking Problem) survey stating that $66.2 \%$ of smokers who tried to stop smoking failed because $42.9 \%$ did not know how and $25.7 \%$ experienced nicotine withdrawal symptoms. ${ }^{9}$

\section{Level of Carbon Monoxide in Exhaled Breath Before and After Treatment}

The mean level of $\mathrm{CO}$ in exhaled breath in the intervention group in pre-test was 12.55 (SD 6.669) and in post-test was 3.75 (4.552). The result of paired samples t-test showed that the value of $\mathrm{p}=0,000$ which means there is a significant difference before and after the hypnotherapy using induction hanung technique. These results are consistent with the Dharmady's findings stating that hypnotherapy treatment in intensive smoking cessation programs can help smokers achieve the cigarette cessation point up to $96 \%$ with the level of CO level in exhaled breath of $\leq 10 \mathrm{ppm}^{22}$

One of suggestions implanted during hypnotherapy is the impact of smoking to the body, especially the $\mathrm{CO}$ gas which is toxic and binding hemoglobin affecting the body tissues experience oxygen deficiency. Anchors or reminders taught are doing alternative habits to take a deep breath whenever the urge to smoke. The findings from F.Joseph et al. revealed that breathing is effective in relieving nicotine withdrawal symptoms due to anxiolytic effects and motoric sensory experiences are similar to smoking. ${ }^{23} \mathrm{CO}$ begins to disappear from the body approximately 5-6 hours after a person stops smoking and it takes maximum 48 hours for smokers to have similar levels of $\mathrm{CO}$ as someone who does not smoke. ${ }^{24}$

The mean level of $\mathrm{CO}$ in exhaled breath in the control group in pre-test was 12.45 (SD 6.932) and in post-test was 13.25 (SD 6.866). The result of paired samples t-test shows the value of $\mathrm{p}=0.474$ which means there is no meaningful difference before and after the implementation of hypnotherapy using induce Hanung techniques. These results prove that without the help ofsmoking cessation methods to achieve cigarette cessation point marked with $\leq 7 \mathrm{ppm}$ of $\mathrm{CO}$ level is a difficult thing to do for active smokers. This is because active smokers have a habit of smoking cigarettes routinely at least one cigarette per day. ${ }^{22}$

\section{Level of cigarette dependence between intervention and control group}

Analysis of average rate result of cigarette dependence between intervention and control groupusing Mann-Whitney test shows that there was statistically significant difference between the two groups where the value of $p=0.028$. The results of this study indicate that hypnotherapy using induction Hanung technique is effective in reducing the level of cigarette dependence for active smokers. These results are consistent with the findings of Gary Elkins stating that intensive treatment of hypnotherapy for 8 sessions to help smokers reduce cigarette dependence with cigarette cessation point reaching $60 \%$ in the first week and last until the $12^{\text {th }}$ week. $^{25}$ 
The evaluation results show that 16 respondents $(80 \%)$ have been free of cigarette dependence with score $=0$ on FTCD measurement after undergoing hypnotherapy using induction hanung technique. This success is related to the early history of respondents who had a mild level of cigarette dependence along with significantly increasing self efficacy scores to the maximum point i.e. score of 10 which means that they were $100 \%$ sure able to quit smoking after undergoing 4 therapies. The 5th and 6th meetings were for maintenance after being ex-smokers in order the smoker self efficacy get higher. This is supported by Somayeh's research stating that hypnotherapy treated in 6 sessions is effective to improve one's self-efficacy. ${ }^{26}$

Four respondents (20\%) showed decrease in their level of cigarette dependence into very light with average score of FTCD measurement was 1 after attending therapy 6 times. Respondents who were unable to reach the point of dependence score $=0$ were due to a history of dependence on early therapy was included in the category of mild level of cigarette dependence with consumption reached 10-20 cigarettes/day. Evaluation results at the cessation stage, all respondents said hypnotherapy helped in lowering the daily consumption of cigarettes but they did not sure to stop smoking totally and had willing to undergo additional therapies until they were declared to be totally cured from cigarette dependence.

\section{Level of Carbon Monoxide between Intervention and Control Group}

Analysis of average rate result of level of $\mathrm{CO}$ in exhaled breath between intervention and control group using independent sample t-test shows that there was statistically significant difference between the two groups with the value of $p=0.000$. The results of this study indicate that hypnotherapy using induction hanung technique is significantly effective in reducing the level of $\mathrm{CO}$ in exhaled breath among active smokers. These results are consistent with Gary Elkins's findings stating that intensive hypnotherapy can help smokers reach cessation points by up to $60 \%$ with measurements of $\mathrm{CO}$ in exhaled breath $\leq 8$ ppm. $^{25}$

Evaluation result at the termination stage shows that 16 respondents $(80 \%)$ had reached the cessation point of cigarette with level of $\mathrm{CO}$ in exhaled breath $\leq 7 \mathrm{ppm}$ after attending therapy 4 times. The $5^{\text {th }}$ and $6^{\text {th }}$ meetings were for maintenance and supervision during the respondents doing their daily activities as the early stage of exsmokers. This success was due to all respondents carried out post-hypnotic suggestion according to the agreement, such as regularly carrying out self hypnosis practice at home at least twice a day before and after sleeping. It is consistent with research from Noha and Sehamwho trained smoking students to apply self-hypnosis at home and showed a decrease in the frequency of smoking every day for nine weeks. ${ }^{18}$

Four respondents (20\%) showed decrease in their level of $\mathrm{CO}$ in exhaled breath to be very mild i.e. 7-15 ppm after attending therapy for 6 times. Respondents who were unable to reach the cessation point of $\leq 7 \mathrm{ppm}$ were caused by the history of smokers who were in the early therapy included in the category of moderate level of cigarette dependence with the level of $\mathrm{CO}$ reached $16-35 \mathrm{ppm}$. The evaluation results in the 
HOLISTIK NURSING AND HEALTH SIENCE 1, (1), 2018 12-23

termination stage shows that all respondents stated they did not routinely performselfhypnosis at home, and did not carry out post hypnotic suggestions according to the agreement.

\section{Relationship between Self-Efficacy with Level of Cigarette Dependence and Carbon Monoxide in Exhaled Breath}

Analysis of the relationship using statistical test showed that the value of $p=0.000$ which means there is a significant relationship between self efficacy, level of cigarette dependence, and level of $\mathrm{CO}$ in exhaled breath among the active smokers. This result is in line with meta-analysis conclusion by Chad et.al. stating that self efficacy or belief of a person to stop smoking predicts the end result of quit smoking effort with a strong relationship (0.47 SD) when self efficacy is assessed after quitting smoking. ${ }^{27}$ Self efficacy is a critical success factor to quit smoking because the low self efficacy causes recurrence in the process of quitting smoking. ${ }^{28}$ The inconsistency of respondents in carrying out self hypnosis during a hypnotherapy program resulted in self efficacy become volatile thereby affecting the final outcome of therapy.

\section{Conclusions}

This study proves that hypnotherapy using induction hanung technique leads to decrease the level of cigarette dependence and $\mathrm{CO}$ in exhaled breath among active smokers. Nurses can use this therapy as a nursing intervention to address the smoking habits in Stop Smoking Clinic with fixed procedures performed for 6 times to active smokers with mildlevel of cigarette dependence and $>6$ times to active smokers with moderate and severe level of cigarette dependence. Future research can be carried out with a periodic evaluation of both short term and long term as well as the need to control the consistent implementation of self hypnosis through respondents' observation sheet.

\section{Acknowledgement}

The authors would like to express a great gratitude to the Director of Kesdam IV/ Diponegoro College of Nursing for giving permission for the researchers to conduct study in his/her institution as well as providing financial support during the study.

\section{References}

1. Ahsan A. Dampak Sosial Ekonomi Konsumsi Tembakau di Indonesia: The $1^{\text {st }}$ Indonesia ConferensceonTobaccoorHealth. Jakarta:TCSC Indonesia;2014.

2. Firzawati. Faktor Upaya Berhenti Merokok pada Perokok Aktif Umur 15 Tahun ke Atas di Indonesia. [Disertasi] Jakarta:Universitas Indonesia; 2015.

3. Achadi A, Soerojo W, Barber S. The Relevance and Prospect of Advancing Tobacco Control in Indonesia. Health Policy Journal.2010;72: 333-349.

4. Shavey O, Erickson M, Rooss H, Mackay J. Tobacco Atlas. Third Edition. Amerika: Cancer Society and World Lung Foundation;2012. 
5. WHO. Code of Practice on Tobacco Control for health Professional Organization Geneva. Who Library Catalouging In Publication Data;2004.

6. Kumar R, Prakash S, Kushwah AS, Vijayan VK. Bearth Carbon Monoxide Devices in Smoking Cessation: Physiology, Controversies and Equipment. The Buyers Guide to Respirratory Care Product;2010.

7. Hughes JR. Nicotine Relative Disorders. 7th edition. Comprehensive Text Book of Psychiaty;2000.

8. Bhattacharyya D, Rai S, Neog L. Therapy for Cessation of Smoking. Medical journal Armed Forces India.2008;64:254-259.

9. Charlotte H, Mitchel M. 100 Question and Answer How to Quit Smoking. 1st Edition. Britton and Barlett Learning;2009.

10. WHO. Fresh And Alive, Mpower; Who report On The Global Tobacco Epidemic. Geneva:World Health Organization;2008.

11. Anderson ET, Judith MF.Community As Partner : Theory and Practice In Nursing. $3^{\text {nd }}$.Philadelphia:Lippincott Williams \& Wilkins;2010.

12. Allender, Judith A, Spradley, Barbara W.Community Health Nurssing : Concept And Practice. $5^{\text {th }}$ Edition.Philadelphia:Lippincott Williams \& Wilkins;2004.

13. Sarna, Linda, Bialous, Stella A. Advancing Nursing Science in Tobacco Control.Volume Editors Annual Review of Nursing Research.NewYork:Springer Publishing Company;2009.

14. Patkar, Ashwin A.A Comparison of Smoking Habits Among Medical and Nursing Students.USA:American College of Chest Physicians;2003.

15. Adi WG. Hypnotherapy The Art of Subconscious Restructuring. Jakarta:PT Gramedia Pustaka Utama; 2006.

16. Hanung P. Hanung Induksi sebagai Induksi Hipnosis yang Efektif, Nyaman, dan Aman. Surakarta: Sinergy Mind Health Indonesia; 2015.

17. Susan H. Hypnosis: Stop Smoking Within One Hour. USA:Eleven Studio; 2011.

18. Noha AM, Seham ME. Effect of hypnotherapy on smoking cessation among secondary school students. Journal of Nursing Education and Practice. 2015;5:6777.

19. Tiffany F, Maria HR, Miguel D. Cortisol decreases and serotonin and dopamine increase following massage therapy. Intern. j. Neuroscience. 2005;115:1397-1413.

20. Hanung P. Advanced Hypnotherapy. Solo: Sinergy Mind Health Indonesia; 2016.

21. Kahija. Hipnotherapi :Prinsip-prinsip Dasar Praktek Psikotherapi, Gramedia Pustaka Utama. Jakarta;2007.

22. Dharmady A. Perception of Private University Student in Jakarta towards Harm Reduction in Drug Addiction Control Program. Global Addiction;2011.

23. F.Joseph MC, Eric CW, Jed ER. The effects of controlled deep breathing on smoking with drawal symptoms in dependent smokers. Addictive Behaviors. 2004;29:765 - 772 .

24. Iin R, Elisna S, Agus DS. Kadar Karbon Monoksida Udara Ekspirasi pada Perokok dan Bukan Perokok serta Faktor-Faktor yang Mempengaruhi. Jurnal Respirasi Indonesia. 2014;34:180-90.

25. Gary E, Joel M, Jeff B, M.Hasan R. Intensive Hypnotherapy for Smoking Cessation: A Prospective Study. Journal of Clinical and Experimental Hypnosis. 2006; 54: 303-315. 
HOLISTIK NURSING AND HEALTH SIENCE 1, (1), 2018 12-23

26. Somayen T, Mehdi P.Effectiveness of Hypnotherapy on Self-concept, Self-efficacy and Exam Anxiety in Girl Guidance School Students in Sari Iran.International Journal of Basic Sciences and Applied Research.2015;4:661-666.

27. Chad JG, Jane M,Christopher WK, \& Saul S. Self-Efficacy and Smoking Cessation: A Meta-Analysis.Psychol Addict Behav. 2009; 23:1-20.

28. Pulungan AT. Proporsi Ketergantungan Nikotin pada siswa/i SMA menggunakan fagestorm test nicotine dependence dan faktor-faktor yang mempengaruhi. Tesis. Jakarta; Program Studi Pulmonologi dan Ilmu Kedokteran Respirasi FKUI;2013. 